\title{
Effects of Sesamol on Experimental Cisplatin Nephrotoxicity Model
}

\author{
Deneysel Sisplatin Nefrotoksisitesi Modelinde Sesamolün Etkileri
}

\author{
Mehmet Emin Dilek', Ali Gurel², Akif Dogantekin ${ }^{3}$, Kazim Sahin ${ }^{4}$, Ibrahim Hanifi Ozercan ${ }^{5}$ Necip Ilhann, \\ Huseyin Celiker ${ }^{7}$
}

${ }^{1}$ Clinic of Internal Medicine, Diyarbakir State Hospital, Diyarbakir; ${ }^{2}$ Nephrology Clinic, Adiyaman University Faculty of Medicine, Adiyaman; ${ }^{3}$ Clinic of Internal Medicine, Emek Hospital, Gaziantep; ${ }^{4}$ Department of Animal Nutrition, ${ }^{5}$ Department of Pathology,

${ }^{6}$ Department of Biochemistry, ${ }^{7}$ Clinic of Internal Medicine, Firat University Faculty of Medicine, Elazig, Turkey

\begin{abstract}
Aim: Cisplatin causes oxidative damage in the kidney. Sesamol is one of the water-soluble and antioxidant compounds of sesame oil. We investigated the effect of sesamol on experimental cisplatin nephrotoxicity and lipid peroxidation.
\end{abstract}

Material and Method: Twenty-eight male Wistar rats were used in 4 groups ( $n=7)$ : control, sesamol (8 mg/kg/day), cisplatin $(7 \mathrm{mg} / \mathrm{kg}$ i.p., single dose), and cisplatin + sesamol. Specimens were evaluated with biochemical, molecular and histopathologic methods. SPSS package programme was used for statistical analyses.

Results: Urea and creatinine levels were significantly higher in the cisplatin group compared to the control group and were significantly decreased in the cisplatin+sesamol group $(p<0.05)$. Cisplatin-treated rats showed a significant increase in malondialdehyde $(M D A)$ levels $(p<0.05)$. Sesamol significantly decreased $M D A(p<0.05)$. Nuclear factor kappa $B(N F-k B)$ levels increased in the cisplatin group compared to the control group and decreased significantly in the cisplatin+sesamol group $(p<0.001)$. Nuclear factor erythroid 2-related factor 2 (Nrf2) and heme oxygenase-1 $(\mathrm{HO}-1)$ levels were decreased in the cisplatin group compared to the control group $(p<0.001)$ and increased significantly in the cisplatin+sesamol group $(p<0.01)$. Histopathological changes with cisplatin decreased with sesamol.

Conclusion: We determined that sesamol decreases lipid peroxidation and NF-KB levels and shows antioxidant effect by increasing Nrf2 and HO-1 levels on cisplatin induced nephropathy.

Key words: cisplatin; nephrotoxicity; sesamol; nuclear factor kappa B; nuclear factor erythroid 2-related factor 2; heme oxygenase-1
ÖZET

Amaç: Sisplatin böbrekte oksidatif hasara neden olmaktadır. Sesamol, susam yağının suda çözünür ve antioksidan bileșenlerinden biridir. Sesamolün, deneysel sisplatin nefrotoksisitesi ve lipid peroksidasyonu üzerindeki etkisini araștırdık.

Materyal ve Metot: Yirmi sekiz erkek, Wistar albino rat dört gruba ayrıld (n=7): konrol, sesamol (8 mg/kg/gün), sisplatin (7 mg/kg i.p., tek doz), ve sisplatin + sesamol. Örnekler biyokimyasal, moleküler ve histopatolojik olarak değerlendirildi. İstatistiksel analiz için SPSS paket program kullanıldı.

Bulgular: Üre ve kreatinin düzeyleri sisplatin grubunda kontrol grubuna göre istatistiksel olarak anlamlı yüksek bulunurken, sisplatin+sesamol grubunda ise anlamlı düșüș görüldü $(p<0,05)$. Sisplatin verilen ratlarda malondialdehid (MDA) düzeylerinde anlamlı artıș saptandı $(p<0,05)$. Sesamol, MDA düzeylerini anlamı ölçüde azalttı $(p<0,05)$. Nükleer faktör kappa $B(N F-k B)$ düzeyleri sisplatin grubunda kontrol grubuna göre istatistiksel olarak anlamlı yüksek bulunurken, sisplatin+sesamol grubunda ise anlamlı düșüș görüldü $(p<0,05)$. Nükleer faktör eritroid 2-ilișkili faktör 2 (Nrf2) ve hem oksijenaz-1 (HO-1) düzeyleri sisplatin grubunda kontrol grubuna göre istatistiksel olarak anlamlı düșük $(p<0,001)$ bulunurken, sisplatin+sesamol grubunda ise anlamlı yükselme görüldü $(p<0,01)$. Sisplatinin neden olduğu histopatolojik değișikliklerin, sesamol uygulamasıyla azaldığı görüldü.

Sonuç: Sesamolün, sisplatin nedenli nefropatide lipid peroksidasyonu ve NF-KB düzeylerini azalttığını ve antioksidan etki göstererek Nrf2 ve HO-1 düzeylerini artırdığını saptadık.

Anahtar kelimeler: sisplatin; nefrotoksisite; sesamol; nükleer faktör kappa B; nükleer faktör eritroid 2-ilișkili faktör 2; hem oksijenaz-1

Iletișim/Contact: Ali Gurel, Nephrology Clinic, Adiyaman University Faculty of Medicine, Adiyaman, Turkey • Tel: 05057535047 • E-mail:draligurel@gmail.com • Geliș/Received:05.08.2019 • Kabul/Accepted:23.07.2020

ORCID: Mehmet Emin Dilek, 0000-0002-1432-3543 • Ali Gürel, 0000-0001-8087-8814 • AkifDoğantekin, 0000-0001-6078-540X • Kazım Şahin, 0000-0001-9542-5244 • İbrahim Hanifi Özercan, 0000-0002-2971-3536 • Necip İlhan, 0000-0001-9997-0418 • Hüseyin Çeliker, 0000-0002-3773-6949 


\section{Introduction}

Cisplatin (cis-diamminedichloroplatinum II) is an important cytotoxic agent, generally used as an effective antineoplastic in many solid tumors, such as cancers of the head, neck, lung, testis, ovary and kidney. It may cause ototoxicity, gastrotoxicity, myelosuppression and allergic reactions ${ }^{1,2}$. Nephrotoxicity is the primary side effect that causes the dose limitation of cisplatin ${ }^{3}$.

Multiple factors play a role in the etiology of cisplatin nephrotoxicity. These factors include reduction in renal blood flow, increased renal vascular resistance, oxidant stress, decreased enzyme activity against peroxidation and changes in the reninangiotensin-aldosterone system. Renal blood flow decreases in the first 3 hours following cisplatin administration. After 48 to 72 hours, proximal tubular dysfunction and renal vascular resistance increases occur. After 72 to 96 hours, GFR decreases. Reversible acute kidney injury is observed in $25 \%$ of patients within 1-2 weeks after cisplatin treatment ${ }^{4}$. Recent studies have shown that inflammation plays an important role in cisplatin-induced kidney damage. Cisplatin increases renal expression of TNF- $\alpha$. TNF- $\alpha$ plays a central role in renal injury; TNF- $\alpha$ induces apoptosis, contributes to the production of reactive oxygen species (ROS) and coordinates the activation of many chemokines and cytokines in the kidney. Studies have shown that TNF- $\alpha$ inhibitors improve cisplatin-induced renal dysfunction by $50 \%$, and reduce structural damage $^{4}$. A large proportion of TNF- $\alpha$ knock-out mice were observed to be protected from cisplatin nephrotoxicity 5 .

Sesamol is a vegetable oil with effects against diseases such as atherosclerosis and hypertension, and has anti-aging properties ${ }^{6}$. Sesamol (5-hydroxy-1.3benzodioxol or 3.4-methylenedioxyphenol) is one of the most important compounds of sesame oil with water-soluble and antioxidant properties ${ }^{7,8}$. Nuclear factor erythroid 2- related factor 2 (Nrf2) is a key factor in cellular stress response. It has been suggested that $\mathrm{Nrf} 2$ has a potential role in cisplatin cytotoxicity and resistance to this drug ${ }^{9,10}$.

Oxygen is an unstable element, found in nature as dioxygen. This unstable structure is formed from oxygen radicals by using two electrons in the outer orbit of another oxygen atom ${ }^{11}$. The initial cause of disorders caused by free radicals is lipid peroxidation (LPO) of the cellular membranes. LPO is defined as a chemical phenomenon initiated by free radicals and causes the oxidation of unsaturated fatty acids in the structure of membranes $^{12}$. Malondialdehyde (MDA), the leading product of LPO, occurs in the peroxidation of fatty acids containing three or more double bonds ${ }^{13,14}$.

Many defence mechanisms have been developed in the body to limit the levels of ROS and their damages. These mechanisms are known as antioxidant defence systems or antioxidants. Antioxidants suppress lipid peroxidation by inhibiting peroxidation chain reaction and collecting $\operatorname{ROS}^{15,16}$. It is known that heme oxygenase (HO) enzyme acts as a protective factor on the endothelium against $\mathrm{ROS}^{17}$. HO1 , the isoform of $\mathrm{HO}$, is severely induced due to oxidative stress (OS) and demonstrates that this enzyme protects the cell against oxidative damage ${ }^{18}$.

In this study, we aimed to investigate the protective effects of sesamol, an antioxidant and anti-inflammatory molecule, on cisplatin nephrotoxicity.

\section{Material and Method}

In this study, 28 male Winstar albino, 10-week-oldrats weighing 200-250 g were obtained from Firat University Experimental Research Centre. Rats were randomly grouped as follows:

1. Control group ( $n=7)$ : On the fourth day, isotonic saline solution $(1 \mathrm{ml} / \mathrm{kg} /$ day $)$ were administered intraperitoneal (i. p.) and fed with a basal diet.

2. Sesamol group $(\mathrm{n}=7)$ : Eight $\mathrm{mg} / \mathrm{kg}$ of sesamol was administered for 10 days in total.

3. CDDP (cisplatin) group $(n=7)$ : On the fourth day, CDDP (CDDP; Sigma Chemical Co., USA) dissolved in $0.9 \%$ saline $(1 \mathrm{ml} / 100 \mathrm{~g} / \mathrm{kg})$ was applied i. p. with $7 \mathrm{mg} / \mathrm{kg}$ dose. Nephrotoxicity was induced by one-time i. p. CDDP injection.

4. Sesamol+CDDP group $(n=7)$ : Rats with both CDDP and sesamol administrations were treated as described above.

Sesamol, dissolved in physiological saline (Sesamol 98\% Sigma Aldrich, Germany), was administered by gavage as an $8 \mathrm{mg} / \mathrm{kg} /$ day dose, 3 days before the beginning of CDDP and continued for a total of 10 days. Six days after the administration of cisplatin, the rats were decapitated under anaesthesia; tissue samples were taken for 
histopathology and western blot and stored at $80^{\circ} \mathrm{C}$ until analysis. The kidneys were removed for histological examination by perfusion via aorta in phosphate buffered solution (PBS; 0.15 $\mathrm{MNaCl}$ and $0.01 \mathrm{M}$ sodium phosphate buffer, $\mathrm{pH}$ 7.4). Blood samples were taken for serum urea nitrogen and creatinine measurements.

Blood samples were centrifuged at $300 \mathrm{G}$ for 10 minutes, and their sera were separated. Serum urea nitrogen and creatinine were measured with a biochemical analyser (Olympus AU-660, Japan). Tissue MDA levels were analysed by high pressure liquid chromatography (HPLC, Shimadzu, Tokyo, Japan), modified from Karatepe ${ }^{19}$.

Kidney tissues were buffered in 1:10 (w/v) [10 mM Tris-HCl, pH 7.4, 0.1 mM NaCl, 0.1 mM phenylmethylsulfonyl fluoride (PMSF), as trypsin inhibitor, $5 \mu \mathrm{M}$ soybean (solute powder); St. Louis, MO, USA)] solution. Tissue homogenates were centrifuged at $15.000 \mathrm{x} \mathrm{g}$ for $30 \mathrm{~min}$ at $4^{\circ} \mathrm{C}$. Supernatants were taken into new tubes. The primary antibodies (Anti-Nrf2 antibody, Anti-NF-kB p65 antibody and Anti Heme Oxygenase 1 antibody; Abcam, Cambridge, UK) was diluted in the same buffer containing $0.05 \%$ Tween-20 at a 1:1000 rate. Protein concentration was measured using the protein measurement kit (Sigma, St. Luis, MO, USA), according to the Lowry procedure.

The left kidney of each rat was fixed with $20 \%$ neutral buffered formalin solution for histological examination. It was then dehydrated slowly and embedded in paraffin. Paraffin blocks were cut into $5 \mathrm{mcM}$ sections in accordance with standard procedures and stained with haematoxylin-eosin dye $\mathrm{e}^{20}$.
Minimun 10 area for each renal slide was examined. A pathologist who was not aware of the treatment groups semiquantitatively evaluated vacuole degeneration, tubular atrophy and dilatation, tubular necrosis, interstitial edema and inflammation.

The Statistical Package for the Social Sciences (IBM-SPSS 22, Chicago, IL, USA) was used for statistical analysis. Quantitative data are presented as mean \pm standard deviation. Statistical differences between the main groups were determined by oneway analysis of variance (ANOVA) followed by the Duncan Post Hoc test. Statistical significance was accepted as $\mathrm{p}<0.05$.

\section{Results}

In terms of urea levels, no significant difference was observed between the control and sesamol groups. However, urea levels in the cisplatin + sesamol group decreased significantly compared to the cisplatin group $(\mathrm{p}<0.05)$ (Table 1).

No significant difference was observed between the control and sesamol groups in terms of creatinine values. Creatinine levels in the cisplatin+sesamol group decreased significantly compared to the cisplatin group $(\mathrm{p}<0.05)$ (Table 1).

There was a significant increase of tissue MDA levelsin the cisplatin group compared to the control group $(\mathrm{p}<0.05)$. Also, the cisplatin+sesamol group was found to be significantly increased $(\mathrm{p}<0.05)$, but a statistically significant decrease was observed compared to the cisplatin group $(\mathrm{p}<0.05)$ (Table 1$)$.

NF-кB levels in kidney samples were analysed by Western blot. There was no statistically significant

Table 1. Effects of sesamol supplementation on serum parameters in rats with cisplatin nephrotoxicity $(n=7)$

\begin{tabular}{lcccc}
\hline & \multicolumn{3}{c}{ Groups } \\
\cline { 2 - 5 } Parameters & Control & Sesamol & Cisplatin & Cisplatin + Sesamol \\
\hline Urea $(\mathrm{mg} / \mathrm{dL})$ & $49.43+1.94^{\mathrm{c}}$ & $44.43+1.54^{\mathrm{c}}$ & $327.00+48.96^{\mathrm{a}}$ & $220.71+40.40^{\mathrm{b}}$ \\
Creatinine $(\mathrm{mg} / \mathrm{dL})$ & $0.280+0.015^{\mathrm{c}}$ & $0.281+0.014^{\mathrm{c}}$ & $3.517+0.739^{\mathrm{a}}$ & $1.830+0.509^{\mathrm{b}}$ \\
MDA $(\mu \mathrm{mol} / \mathrm{L})$ & $0.337 \pm 0.028^{\mathrm{c}}$ & $0.302 \pm 0.015^{\mathrm{c}}$ & $1.938 \pm 0.203^{\mathrm{a}}$ & $1.319 \pm 0.094^{\mathrm{b}}$ \\
NF-KB & $100 \pm 10.96^{\mathrm{c}}$ & $103.13 \pm 13.74^{\mathrm{c}}$ & $223.66 \pm 11.13^{\mathrm{a}}$ & $168.18 \pm 4.4^{\mathrm{b}}$ \\
Nrf2 & $100 \pm 5.90^{\mathrm{a}}$ & $96.93 \pm 5.43^{\mathrm{a}}$ & $34.45 \pm 3.40^{\mathrm{c}}$ & $54.45 \pm 5.07^{\mathrm{b}}$ \\
HO-1 & $100 \pm 0.43^{\mathrm{a}}$ & $97.63 \pm 2.72^{\mathrm{a}}$ & $69.50 \pm 2.94^{\mathrm{c}}$ & $83.82 \pm 2.56^{\mathrm{b}}$ \\
\hline
\end{tabular}

MDA: malondialdehyde, NF-KB: nuclear factor kappa B, Nrf2: nuclear factor erythroid 2-related factor 2, H0-1:heme oxygenase-1.

Values are presented as mean and standard error.

$\mathrm{NF}-\mathrm{KB}, \mathrm{Nrf2}, \mathrm{HO}-1$ indicated as $\%$ of control group. 


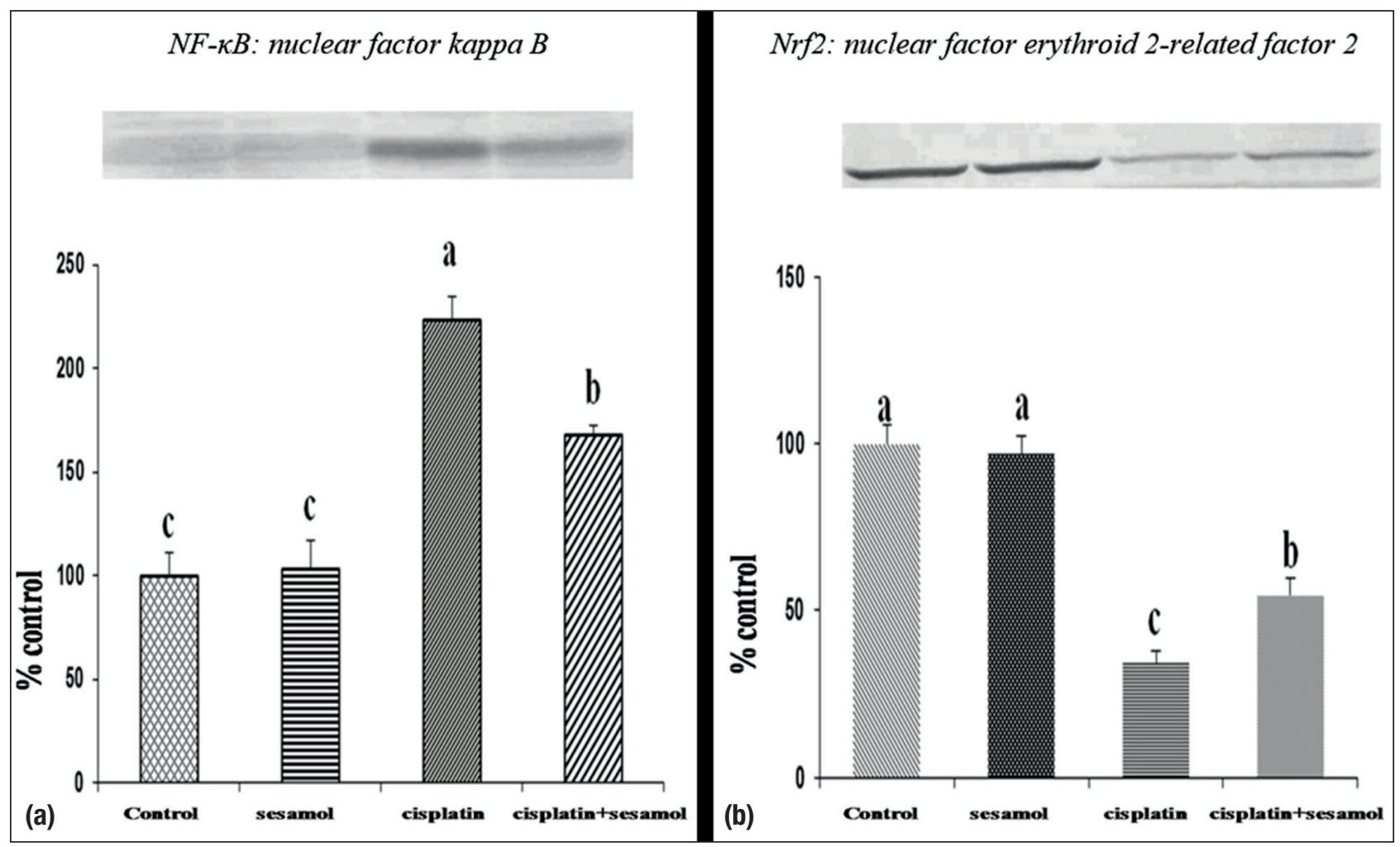

Figure 1. $\boldsymbol{a}, \boldsymbol{b}$. Effect of sesamol on serum NF-KB (a) and Nrf2 (b) level in rats treated with cisplatin nephrotoxicity.

difference between the control and sesamol groups in terms of NF-kB levels ( $p>0.05)$. When the cisplatin and control groups were compared, a statistically significant increase was observed in the cisplatin group $(\mathrm{p}<0.001)$. In the cisplatin + sesamol group, a significant increase was observed compared to the control group $(\mathrm{p}<0.001)$, but a statistically significant decrease was observed when compared tothe cisplatin group $(\mathrm{p}<0.001)$ (Figure 1).

There was no statistically significant difference between the control and sesamol groups $(\mathrm{p}>0.05)$. When the cisplatin and control groups were compared, a statistically significant decrease was observed in the cisplatin group $(\mathrm{p}<0.001)$. Although Nrf2 expression of the cisplatin+sesamol group decreased significantly in comparison with the control group $(p<0.001)$, but increased significantly when compared with the cisplatin group $(p<0.01)$.

There was no statistically significant difference between the control and sesamol group$\sin$ terms of HO-1 $(\mathrm{p}>0.05)$. In the cisplatin and cisplatin+sesamol groups, there was a significant decrease in comparison with the control group $(p<0.001)$. On the other hand, in the cisplatin+sesamol group, HO-1 levels increased significantly compared to the cisplatin group $(\mathrm{p}<0.001)$.

Mild interstitial oedema was observed in the kidneys taken from the control and sesamol groups. In the cisplatin group, mild vacuolization, interstitial oedema, interstitial inflammation, moderate tubular atrophy and tubular necrosis were observed. Tubal necrosis, tubular atrophy, vacuolization, and interstitial inflammation decreased in the cisplatin + sesamol group.

\section{Discussion}

The use of antineoplastic drugs with nephrotoxic properties in the treatment of tumours has begun to cause chronic kidney disease development more often due to chemotherapy ${ }^{21}$. Cisplatin is an antineoplastic agent with high antitumoral activity and has a wide range of use. However, the dose-dependent nephrotoxic effect limits its use. The cellular mechanism of cisplatin nephrotoxicity is not fully known. Therefore, to understand the mechanism of 
toxicity, the effect of cisplatin has been studied in various animal models ${ }^{22}$.

Oxidative stress plays an active role in cisplatininduced acute kidney injury. ROS may be produced by xanthine-xanthine oxidase, mitochondria and nicotinamide adenine dinucleotide phosphate oxidase (NADPH oxidase) in the cells in OS states.

Cisplatin activates all these pathways. These oxidant molecules act directly on cell components, such as lipids, proteins and DNA and disrupt their structures. MDA, a product of lipid peroxidation, has been shown to increase in renal tissue as a result of $\mathrm{OS}^{23}$.

In our study, as in many cisplatin model studies, it was observed that nephrotoxicity successfully developed in cisplatin-treated rats. Serum urea and creatinine levels were significantly increased in cisplatin-treated rats compared to the control and sesamol groups. Histopathological examination revealed significant renal injury in the cisplatin group. Also in the cisplatin group, MDA and transcriptional factor NF-kB levels were significantly increased while a significant decrease was observed in Nrf2 and HO-1 levels.

Kuhad et al. ${ }^{24}$ investigated the protective effects of sesamol treatment in an experimental diabetes model. They observed that sesamol supplementation, in addition to streptozocin, significantly decreased serum urea and creatinine values compared to streptozocin alone. Also, sesamol has been shown to reduce OS due to sepsis and to prevent organ damage. Similarly, Gupta et al. ${ }^{25}$ showed the protective effect of sesamol on ferric nitrilotriacetate-induced nephrotoxicity in an experimental study. Hsu et al. ${ }^{26}$ also investigated the protective effect of sesamol against ferric nitrilotriacetateinduced acute renal insufficiency, and shown that serum urea and creatinine levels were significantly lower in patients who received sesamol with cisplatin. In our study, despite the elevation of serum urea and creatinine levels in the cisplatin group, sesamol significantly decreased nephrotoxic effect. We found a significant decrease in tissue MDA levels in the cisplatin+sesamol group compared to cisplatin group. In a similar study, Chu et al. ${ }^{27}$ investigated the effects of sesamol on OS in serulein-induced acute pancreatitis and found a significant decrease in lipid peroxidation in the sesamol+ serulein treated group compared to the serulein-alone group. Kuhad et al. ${ }^{28}$ investigated the protective effects of sesamol on cognitive decline in diabetic mice. They found a significant decrease in MDA levels in the brain tissue group in the sesamol+streptozocin group compared to the streptozocin-receiving rats. The data obtained in our study is compatible with the data in the literature. It has been determined that the inhibition of lipid peroxidation plays an important role in the protective effect of sesamol against cisplatin nephrotoxicity. The role of oxidative damage in cisplatin nephrotoxicity has been reported in various studies.

Previous studies have shown that cisplatin increases the formation of ROS, reduces antioxidant enzyme levels and induces apoptosis. One study reported that ROS due to cisplatin caused an increase in NF$\mathrm{kB}$ formation ${ }^{29}$. In our study, we found a significant increase in NF-kB level in the cisplatin group compared to the control and sesamol groups. However, we found a significant decrease in tissue NF-kB level in the sesamol+ cisplatin group compared to the cisplatin group. Similar results have been obtained in many studies where the relationship between sesamol, and NF-kB was investigated. As mentioned above, Kuhad et al. ${ }^{24}$ studied the protective effect of sesamol in an experimental diabetic nephropathy model and reported that sesamol significantly decreased NF-кB levels and found a preventive action against nephropathy. In their experimental cardiometabolic syndrome model, Sharma et al. ${ }^{30}$ found a significant decrease in NF-KB levels in the hepatic tissue ofrats receiving a sesamol+fat rich diet compared to a group that received only fat. In another study, Chang et al. ${ }^{31}$ reported that sesamol inhibited the NF-кB signal pathway in platelet activation.

Nuclear factor kappa B provides expression of many genes involved in inflammation, embryonic development, lymphoid differentiation, oncogenesis and apoptosis, whereas Nrf2 is a transcription factor that regulates the transcription of antioxidant enzymes, such as HO-1, NAD (P) H: quinine oxidoreductase-1, c-glutamylcysteine sentase and glutathione S-transferase. Nrf2 increases the production of antioxidant enzymes, such as HO-1, and protects cells against oxidative stress ${ }^{32}$. Many studies have shown an inverse relationship between NF-kB and Nrf2. 

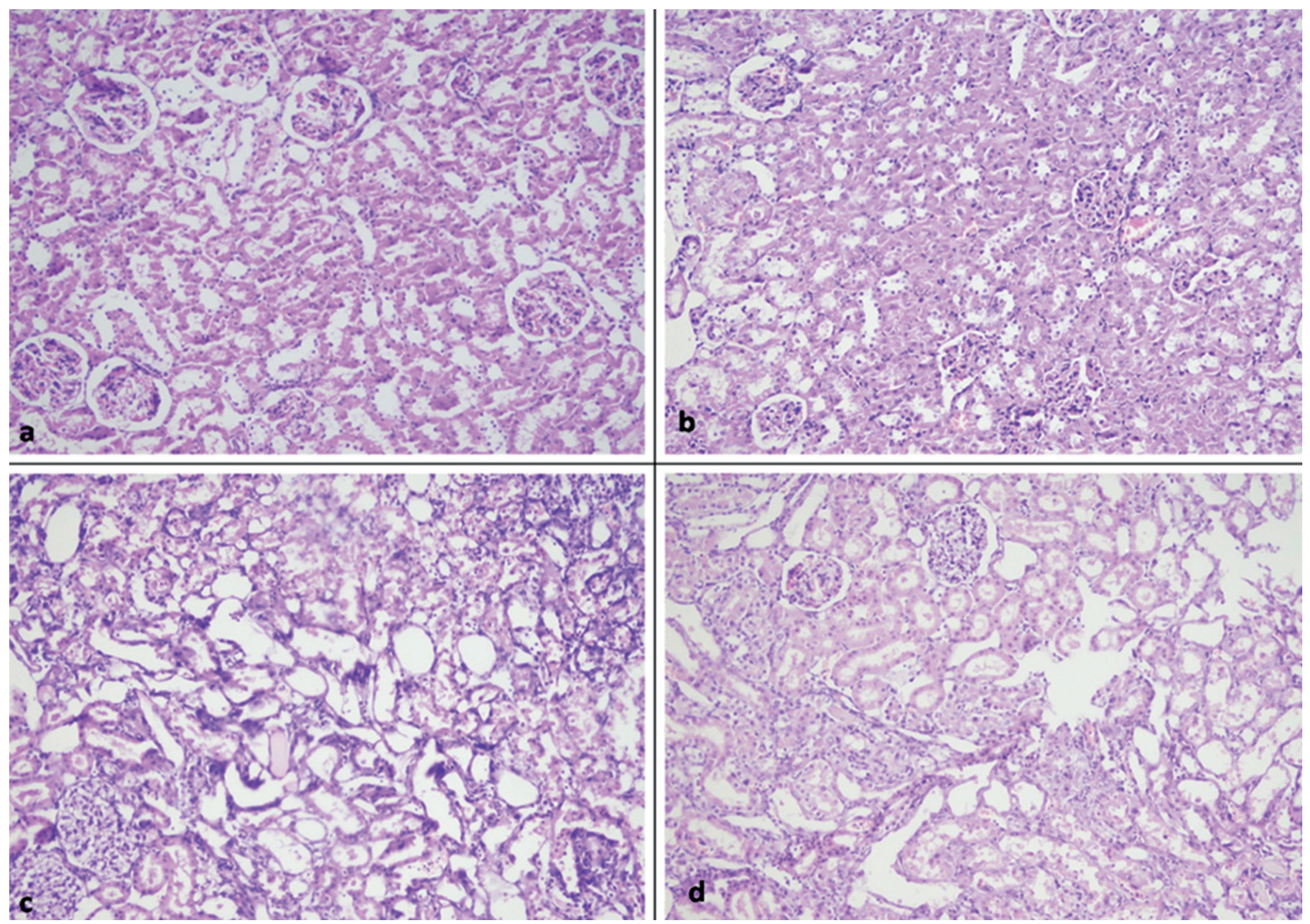

Figure 2. Effect of sesamol administration in cisplatin nephrotoxicity on morphological changes in rat kidney tissue, as described above.

In an experimental study, Kılıç et al. ${ }^{33}$ reported the protective effect of melatonin against cisplatin nephrotoxicity by increasing $\mathrm{Nrf} 2 / \mathrm{HO}-1$ and decreasing NF-kB levels. In our study, we found asignificant decrease inHO-1 and Nfr2 levels in the rats receiving cisplatin. Compared to the cisplatin group, Nrf2 and HO-1 levels were significantly increased in the sesamol+cisplatin group. To the best of our knowledge, no other study of the relationship has addressed the relationship between sesamol and Nrf2/HO-1.

The study by Parlakpinar et al. ${ }^{34}$, reported dilated tubules, damaged glomeruli, interstitial oedema and focal inflammation in the kidney damage induced by the cisplatin model. Özyurt et al. $^{35}$ reported tubular epithelial vacuolisation, cellular swelling and spillage due to cisplatin's effects. In our study, we observed tubular vacuolisation, interstitial inflammation, interstitial oedema, tubular atrophy and tubular necrosis due to cisplatin, and noted significant healing in the sesamol+cisplatintreated rats.

In their experimental study, Liu $\mathrm{Z}$ et al. ${ }^{36}$, demonstrated that sesamol alleviated systemic inflammation-induced amyloidogenesis and cognitive deficits by preventing neuron damage, suppressing glia activation, and down-regulating inflammatory responses with anti-neuroinflammatory effects of sesamol via blocking translocation and DNA binding activity of NFkB and, they presented sesamol as a treatment option for amyloidogenesis and neuroinflammation.

Sesamol was also observed to attenuate systemic lipopolysaccharide-induced lung inflammation by inhibiting the alveolar macrophage inflammatory response in rat model $^{37,38}$.

In conclusion, we determined that sesamol decreases lipid peroxidation and proinflammatory NF- $\mathrm{kB}$ 
levels andincreases antioxidant $\mathrm{Nrf} 2$ and HO-1 levels. Sesamol has a protective effect against cisplatin nephrotoxicity by reducing OS and inflammation in kidney tissue.

\section{References}

1. Osanto S, Bukman A, Van Hoek F, Sterk PJ, De Laat JA, Hermans J. Long-term effects of chemotherapy in patients with testicular cancer. J Clin Oncol 1992;10:574-9.

2. Hartmann JT, Fels LM, Knop S, Stolt H, Kanz L, Bokemeyer C.A randomized trial comparing the nephrotoxicity of Cisplatin/ifosfamide-based combination chemotherapy with or without amifostine in patients with solid tumors. Invest New Drugs 2000;18:281-9.

3. Sastry J, Kellie SJ. Severe neurotoxicity, ototoxicity and nephrotoxicity following high-dose cisplatin and amifostine. Pediatr Hematol Oncol 2005;22:441-5.

4. Yao X, Panichpisal K, Kurtzman N, Nugent K. Cisplatin nephrotoxicity: a review. Am J Med Sci 2007;334:115-24.

5. Ramesh G, Reeves WB. TNFR2-mediated apoptosis and necrosis in Cisplatin-inducedacuterenal failure. Am J Physiol Renal Physiol 2003;285:610-8.

6. Fukuda Y, Osawa T, Namiki M, Ozaki T. Studies on antioxidative substances in sesame seed.Agric Biol Chem 1985;49:301-6.

7. Hsu DZ, Chen KT, Li YH, Chuang YC, Liu MY. Sesamol delays mortality and attenuates hepatic injury after cecal ligation and puncture in rats: role of oxidative stres. Shock 2006;25:528532.

8. Parihar VK, Prabhakar KR, Veerapur VP, Kumar MS, Reddy YR, Joshi Ret al. Effect of sesamol on radiation-induced cytotoxicity in Swiss albino mice. Mutat Res 2006;611:9-16.

9. Cho JM, Manandhar S, Lee HR, Park HM, Kwak M. Role of the Nrf2-antioxidant system in cytotoxicity mediated by anticancer Cisplatin: Implication to cancer cell resistance. Cancer letters 2008;260:96-108.

10. So HS, Kim H, Kim Y, Kim E, Pae HO, Chung HT et al. Evidence that Cisplatin-induced auditory damage is attenuated by downregulation of pro-inflammatory cytokines via $\mathrm{Nrf2/}$ HO-1. J Assoc Res Oto 2008;9:290-306.

11. Winrow VR, Winyard PG, Morris CJ, Blake DR. Free radicals in Inflammation. Secondmessergers and mediators of tissue destruction. British Medical Bulletin 1993:506-22.

12. Kalender S, Kalender Y, Ogutcu A, Uzunhisarcikli M, Durak D, Açikgoz F. Endosulfan-induced cardiotoxicity and free radical metabolizm in rats: the protectiveeffect of vitamin $\mathrm{E}$. Toxicology 2004:202;227-35.

13. Valko M, Leibfritz D, Mancol J, Cronin MTD, Mazur M, Telser J. Free radicals and antioxidants in normal physiological functions and human disease. IntJ Biochem\&Cell Biology 2007:39;44-84.
14. Valko M, Rhodes CJ, Mancol J, Izakovic M, Mazur M. Free radicals,metals andantioxidants in oxidative stres-induced cancer. Chemico-Biological Interactions 2006:160;1-40.

15. Cheeseman KH, Slater TF. An introduction to free radical biochemistry. Br MedBull 1993;49:479-80.

16. Isbir T. Antioksidan Sistemler. Endotel. İzmir Tabib Odası Tipta Temel Bilimler Kolu Sonbahar Okulu 1994;21:92-8.

17. Abraham NG, Lavrovsky Y, Schwartzman ML, Stoltz RA, Levere RD, Gerritsen ME et al. Transfection of the human heme oxygenase gene into rabbit coronary microvessel endothelial cells: protective effect against heme and hemoglobin toxicity. ProcNatlAcadSci 1995;92:6798-802.

18. Motterlini R, Foresti R, Intaglietta M, Winslow RM. NO-mediated activation of heme oxygenase: endogenous cytoprotection against oxidative stress to endothelium. Am J Physiol1996;270:107-14.

19. Karatepe M. Simultaneous determination of ascorbic acid and free malondialdehyde in human serum by HPLC/UV. LC-GC North America 2004;22:362-5.

20. Ross MH, Reith EJ. Methods. Ross MH, Reith EJ, Romrell LJ (Eds). Histology-A Text and Atlas. Maryland: Williams and Wilkins, Baltimore, 1989:1-13.

21. Çıtak A, Alpay H, Nayır A. Antineoplastik ilaçlara bağlı böbrek yetersizliği. İstanbul: Tip Fakültesi Mecmuası 1995;58:116-9.

22. Antunes LM, Darin JD,Bianchi ND. Effects of the antioxidants curcumin or selenium on cisplatin-induced nephrotoxicity and lipid peroxidation in rats. Pharmacol Res 2001;43:145-50.

23. Santos NA, Catão CS, Martins NM, Curti C, Bianchi ML, Santos AC. Cisplatin-induced nephrotoxicity isassociated with oxidative stress, redox state unbalance, impairment of energetic metabolism and apoptosis in rat kidney mitochondria. Arch Toxicol 2007; 81: 495-504.

24. Kuhad A, Sachdeva AK,Chopra K. Attenuation of renoinflammatory cascade in experimental model of diabetic nephropathy by sesamol. J Agric Food Chem 2009; 57: 6123-8.

25. Gupta A, Sharma S, Kaur I, Chopra K. Renoprotective effects of sesamol in ferricnitrilotriacetate-induced oxidative renal injury in rats. Basic Clin Pharmacol Toxicol 2009;104:316-21.

26. Hsu DZ, Wan CH, Hsu HF, Lin YM, Liu MY. The prophylactic protective effect of sesamol against ferric-nitrilotriacetateinduced acute renal injury in mice. Food Chem Toxicol 2008; 46:2736-41.

27. Chu PY, Srinivasan P, Deng JF, Liu MY. Sesamol attenuates oxidative stress-mediated experimental acute pancreatitis in rats. Hum Exp Toxicol 2012;31:397-404.

28. Kuhad A, Chopra K. Effect of sesamol on diabetes-associated cognitive decline in rats. Exp Brain Res 2008; 185:411-20.

29. Li Q, Verma IM. NF-kappaB regulation in the immune system. Nat Rev Immunol 2002;2:725-34.

30. Sharma AK, Bharti S, Bhatia J, Nepal S, Malik S, Ray Ret al. Sesamol alleviates diet-induced cardiometabolic syndrome in rats via up-regulating PPAR $\gamma, \operatorname{PPAR} \alpha$ and e-NOS. J Nutr Biochem 2012;23:1482-9. 
31. Chang CC, Lu WJ, Ong ET, Chiang CW, Lin SC, Huang SY, et al. A novel role of sesamol in inhibiting NF-B mediated signaling in platelet activation. Journal of Biomedical Science 2011;18:93.

32. Surh YJ, Kundu JK, Na HK. Nrf2 as a master redox switch in turning on the cellular signaling involved in the induction of cytoprotective genes by some chemopreventive phytochemicals. Planta Med 2008;74:1526-39.

33. Kilic U, Kilic E, Tuzcu Z, Tuzcu M, Ozercan IH, Yilmaz O et al. Melatonin suppresses cisplatin induced nephrotoxicity via activation of Nrf-2/HO- 1 pathway. Nutr Metab 2013;10:7.

33. Parlakpinar H, Sahna E, Ozer MK, Ozugurlu F, Vardi N, Acet A. Physiological and pharmacological concentrations of melatonin protect against Cisplatin-induced acute renal injury. J Pineal Res 2002;33:161-6.

34. Ozyurt H, Yildirim Z, Kotuk M, Yılmaz HR, Yağmurca M, Iraz $\mathrm{M}$, et al. Cisplatin-induced acute renal failure is ameliorated by erdosteine in a dose-dependent manner. J Appl Toxicol 2004;24:269-75.
35. Liu Z, Chen Y, QiaoQ, Sun Y, Liu Q, Ren B et al. Sesamol Supplementation Prevents Systemic Inflammation-Induced Memory Impairment and Amyloidogenesis via Inhibition of Nuclear Factor kappaB.Mol Nutr Food Res2017 May;61(5). doi: 10.1002/mnfr.201600734. Epub 2016 Dec 30.

35. Chu PY, Chien SP, Hsu DZ, Liu MY. Protective Effect of Sesamol on the Pulmonary Inflammatory Response and Lung Injury in Endotoxemic Rats. Food Chem Toxicol 2010 Jul;48(7):1821-6. doi: 10.1016/j.fct.2010.04.014. Epub 2010 Apr 14.

36. Chu PY, Hsu DZ,Hsu PY, Liu MY. Sesamol DownRegulates the Lipopolysaccharide-Induced Inflammatory Response by Inhibiting Nuclear Factor-Kappa B Activation. Innate Immun 2010 Oct;16(5):333-9. doi: 10.1177/1753425909351880. Epub 2009 Nov 25. 